\title{
Phosphorylated Tau Protein Measurement
}

National Cancer Institute

\section{Source}

National Cancer Institute. Phosphorylated Tau Protein Measurement. NCI Thesaurus. Code C84812.

The determination of the amount of phosphorylated Tau protein present in a sample. 